\title{
I WANT TO COMPLAIN
}

The BDJ Upfront section includes editorials, letters, news, book reviews and interviews. Please direct your correspondence to the News Editor, Kate Quinlan at the BDJ, The Macmillan Building, 4 Crinan Street, London, N1 9XW or by email to k.quinlan@nature.com

Press releases or articles may be edited, and should include a colour photograph if possible.

Stephen Hancocks OBE

Editor-in-Chief

$\mathrm{T}$ here is a sinister sense of less than quiet irony that the first thing we are taught to record in a patient's notes, after the medical history, are the three words; patient complains of...

The fact of the matter is that more patients have been complaining than ever before, which the General Dental Council (GDC) has taken enormous glee in telling everyone. In fact I was recently invited on to $\mathrm{BBC}$ Radio Five Live to take part in a debate on the subject. We have been told for some time that complaints against us have been increasing but to date there has been little discussion of the context in which the rise has been taking place. In a recorded interview on the live radio programme GDC Chief Executive and Registrar Evlynne Gilvarry explained that complaints against dentists had risen by one hundred per cent in five years, although also adding that very few of these progressed through to the most serious level. It is also useful to put this in context of overall numbers. According to the most recent GDC Update, in 2013 there was a $31 \%$ increase in the number of complaints received compared with 2012 (2,278 vs 2,988). ${ }^{1}$ This is from a registrant population currently numbering over 104,000 with dentists just short of 40,000 and an annual number of courses of dental treatment measured in tens of millions. In 2012, the last year for which I can find figures, 34 dentists' names were erased from the Dentist Register.

What I find disingenuous is that to date no one of whom I have been aware has chosen to put this in a wider context still, that of professionals other than dentists. Yet on investigation I discover that the

\section{'More patients have been complaining than ever before...'}

General Medical Council announced last autumn that complaints against doctors had increased by over one hundred percent in the previous five years and the Legal Ombudsman has recorded similar increases in various categories of legal professionals and particularly amongst solicitors. In this regard, though of course not scientific, typing the words "complaints against' into a Google search brings up the predictive text of the next word as, in order; solicitors, police, social services, estate agents and schools. Try it for yourself, you will see that dentists are a long way down the list.

So, we are not alone and are experiencing this as a change in society. Not that I am suggesting any grounds for complacency, nor suggesting that any of these complaints may not have been legitimate. Indeed, the vast majority of us see complaints as pro-active ways of improving our care. But it is still a small problem despite those who would spread woe. And why would they do so? The GDC styles itself as protecting patients and therefore it is in its own interests to proclaim how much better job it is seen to be doing by increasing patient reaction. Also on the radio programme, and literally invited to give "the last word' was a dentist turned lawyer whose company specialises in garnering patients with grievances. Vociferously advocating that the complaints that he and his colleagues see are just the tip of an iceberg of malpractice and misdemeanours it is hardly surprising since they also, literally, make their living from such cases.

Hand-in-hand with these figures has been a change in the ease with which complaints can be made. Previously, for example, complaints to the GDC had to be accompanied by a sworn affidavit from a lawyer. This was an obvious barrier (and I am not advocating a return to this system) often criticised as being expensive but this was a reflection of legal costs not healthcare costs. In recent years the GDC also originated the private patients' complaint service, funded from annual retention fees, in its turn creating a new conduit for communications.

Additionally, we have moved to a society more comfortable with the nature of whistle blowing. How many of the much publicised "celebrity' abuse cases might have been prevented were a similar ethos in place in the past? There is also less stigma against such actions between colleagues and health systems than previously; another laudable development. However, just prior to writing this editorial one news item caught my eye. The Professional Standards Authority (www.professionalstandards.org.uk), the body charged with validating the integrity of professional regulators, announced that: 'Following concerns raised with us by a whistleblower about the management and support processes of the General Dental Council's Investigating Committee, we have decided to carry out an investigation. The matters to be investigated are: The GDC's: a) management of the processes and support for its investigating committees which post-dates the publication of our Investigation report "An investigation into concerns raised by the former Chair of the General Dental Council (February 2013)”...

You know what? I want to complain.

1. GDC Update. May 2014. London: GDC. DOI: 10.1038/sj.bdj.2014.454 